\title{
Chronic dietary aflatoxins exposure in Kenya and emerging public health concerns of impaired growth and immune suppression in children
}

\author{
Eddy OWAGA ${ }^{1 *}$, Richard MUGA $^{2}$, Hazel MUMBO ${ }^{2}$ and Fredrick AILA ${ }^{2}$ \\ ${ }^{1}$ Department of Food Science and Technology, Kimathi University College of Technology.P.O. Box 657-10100, \\ Nyeri, Kenya. \\ ${ }^{2}$ Department of Enterprise, Great Lakes University of Kisumu. P.O. Box 2224 - 40100, Kisumu, Kenya. \\ *Corresponding author, E-mail: eowaga@yahoo.co.uk
}

\begin{abstract}
Aflatoxins are toxic secondary metabolites produced by fungi and contaminate various agricultural commodities either before harvest or under post-harvest conditions. Acute aflatoxin poisoning leading to casepatients and deaths has continued to occur in several parts of Kenya. However, there is emerging evidence implicating chronic aflatoxins exposure as an important factor in infant growth stunting and immune suppression. The consumption of smaller dosages overtime produces no obvious symptoms as would happen with acute dosage. Thus, it has not attracted much attention in Kenya in terms of public health priorities. Aflatoxins have been detected mainly in the staple foods such as cereals and legumes commodities, which form the main gruel ingredients used to compose weaning foods in most rural households. This suggests that children may be more exposed to mycotoxins than the rest of the population and this could be the reason for increased cases of infant malnutrition and mortality in certain areas in Kenya. The extent to which stunted growth and immune suppression contribute to the overall burden of infectious disease merits consideration. Therefore, this paper discusses dietary chronic mycotoxins exposure in Kenya and emerging public health concerns of stunted growth and immune suppression as reported in various related animal and human studies. It also highlights several factors that may enhance the dietary mycotoxins exposure especially amongst children and further explores various localized control measures and research areas within the context of food scarcity and extreme poverty experienced in rural Kenya. This paper aims at reinforcing that presence of mycotoxins within the food system should be addressed as an urgent food safety issue as they place a significant hindrance towards the attainment of the Millennium Development Goals (MDGs) 4 and 6 on reduction of child mortality and combating of diseases, respectively.
\end{abstract}

(C) 2011 International Formulae Group. All rights reserved.

Keywords: Dietary aflatoxins exposure, growth impairment, immune suppression, children.

\section{Health indicators of children in Kenya}

Child mortality still remains a critical problem in Kenya. The Kenya Demographic Health Survey (KDHS) 2008-2009 survey indicates that the national under-five and child mortality rates have declined from 115 per
1,000 live births and $41 \%$ in 2003 to 74 per 1,000 live births and $23 \%$ respectively in 2008-2009 mainly as a result of improved immunization of children (CBS, 2004). Nevertheless, the national child health indicators have not improved significantly 
over the past years especially at the provincial level where the rates display considerable differentials (Kabubo-Mariara et al., 2006). The mortality rates have remained intolerably high in some regions such as Nyanza Province having 133 (infant) and 206 (child) deaths per 1,000 live births (CBS, 2004). The KDHS 2003 survey indicates that about $29 \%$ of child deaths occurring in the first five years of life take place within one month after birth (neonatal mortality), while $66 \%$ occur within the first one year and the remaining $34 \%$ in the remaining $1-4$ years. The challenge therefore remains to understand and work on the causes of infant and child mortality especially within the first month after birth, if any progress is to be achieved in reducing child mortality. Amongst the leading causes of infant and child deaths in Kenya include malnutrition, respiratory infections especially pneumonia, diarrhea, malaria, measles, and Human Immunodeficiency virus (HIV/AIDS) (Ikamari, 2004; MPND, 2005).

Although dietary mycotoxins are not specifically mentioned, they may play a modulating role in a certain number of these factors. Fetal and early childhood environment is important for growth and disease risk in later life because it is the most critical time for the immune system development (Hendrickse, 1991). This implies that the causal associations between mycotoxin exposure and impaired growth; and immune suppression have significant effects on other aspects of child health, such as susceptibility to infectious diseases (Hendrickse et al., 1997; Terry and Susser, 2001). From this perspective, chronic dietary mycotoxin exposure amongst infants and children is a major concern in Kenya, particularly as a hindrance towards the attainment of the MDGs 4 and 6 on reduction of child mortality and combating of HIV/AIDs, malaria and other diseases (Williams et al., 2004). Therefore, there is urgent need to implement management strategies to reduce dietary mycotoxins exposure to levels below the regulatory limits.
Dietary mycotoxins exposure in Kenya

Mycotoxins are toxic secondary metabolites produced by fungi and contaminate various agricultural commodities either before harvest or under post-harvest conditions (Bhat et al., 2010). The most important mycotoxins of public health concern are aflatoxins, ochratoxins, deoxynivalenol (DON), zearalenone, fumonisin and trichothecenes. The main genera of fungi that produce mycotoxins in foods are Aspergillus spp, Penicillium spp and Fusarium spp. The toxins that are of greatest significance in tropical developing countries including Kenya are fumonisins and aflatoxins (Bankole et al., 2006; Wild, 2007).

The presence of mycotoxins in food is often overlooked in Kenya, mainly due to the public ignorance about their existence and lack of effective regulatory mechanisms. Repetitive incidents of acute mycotoxicosis have re-occurred during periods 1981, 2001, 2004 and 2005 (CDC, 2004; Lewis et al., 2005). In 2004, 317 case-patients and 125 deaths were recorded in the eastern and central districts and were associated with aflatoxin poisoning, which arose from maize stored under damp conditions (Lewis et al., 2005). A similar outbreak occurred in the eastern districts of Kenya in 2005 resulting to 75 case-patients and 32 deaths. Survey of the affected region showed maize samples were contaminated with aflatoxin levels above 20 $\mu \mathrm{gkg}^{-1}$ legal limit (Azziz-Baumgartner et al., 2005; Muture and Ogana, 2005; Probst et al., 2007; Muthama et al., 2009). Smaller outbreaks have also been reported, resulting in 20, 12 and 9 deaths in 1981, 2001 and 2006, respectively (DN, 2001). Nevertheless, due to the remoteness of villages in the affected districts in Kenya and the large geographic area involved, the data on outbreak case findings have largely been limited to records from medical facilities. It is possible that some chronically affected persons might not have been able to reach health-care facilities for diagnosis and treatment; hence the true 
magnitude of the outbreaks is likely to be considerably greater than reported.

Aflatoxins contamination of staple foods is prevalent within Kenya due to the prevailing hot and humid, tropical, or droughtlike conditions that are ideal for the fungal growth and mycotoxin proliferation (Kabak et al., 2006). Aflatoxins are capable of accumulating in wide range of food commodities namely cereals, legumes, meat, dried fish, egg and milk products (Muriuki and Siboe , 1995; Egal et al., 2005; Bankole et al., 2006; Wagacha and Muthomi, 2008; Muthama et al., 2009). Most weaning foods in Kenya are derived from maize, groundnuts, sorghum, millet, dried fish, beans, cassava, rice and green grams. The Aspergillus spp and Fusarium spp, have been identified as the predominant fungi in weaning food gruel mixtures leading to contamination to as high as $82 \mu \mathrm{gkg}^{-1}$ of aflatoxins (Okoth and Ohingo, 2004). Children of weaning age are, therefore, most susceptible to the mycotoxic risks because their diets are less varied, alternating between breast milk and weaning gruel.

\section{Emerging public health concerns of dietary aflatoxins exposure \\ Impaired growth of children}

Aflatoxins (types $B_{1}, B_{2}, G_{1}$, and $G_{2}$ ) are of particular public health importance because of their carcinogenic actions on human health (IARC, 1993). Ingestion of higher doses of aflatoxin can result in acute aflatoxicosis, which manifests as liver cancer and jaundice (Fung and Clark, 2004; Shephard, 2008; Lamplugh and Hendrickse, 1982). Chronic mycotoxic exposure, the consumption of smaller dosages overtime, is regarded as a 'silent killer' poison because the toxic chemicals are not detected by human antigens, hence produce no obvious symptoms as would happen with acute dosage. It has, therefore, not drawn much attention in Kenya in terms of public health priorities. Recently published reports indicate emerging evidence that both growth impairment and immune function are directly affected by cumulative chronic mycotoxin exposure in developing countries. According to studies conducted in Benin and Togo by Gong et al. (2002), aflatoxin exposure increases at weaning stage and can lead directly to growth impairment and stunting of growth in infants. The AF-alb level increased with age up to 3 years, and within the 1-3 year age group was significantly related to weaning status; weaned children had approximately two fold higher mean AF-alb adduct levels (38 pgmg $^{-1}$ ) than those receiving a mixture of breast milk and solid foods. It was also observed that stunted children had 30-40\% higher mean AF-alb levels than other children in the study. The authors also observed strong doseresponse relationships between AF-alb levels and the extent of stunting and being underweight.

Other authors have also reported on kwashiorkor (usually attributed to protein energy malnutrition) and chronic aflatoxin exposure (Hendrickse et al., 1982; 1984; 1991; Coulter et al., 1986; Katere et al., 2008). A study conducted in Kisumu district, Kenya, by Okoth and Ohingo (2004), observed that $31 \%$ of the young children were malnourished and the correlation between the number of children who were wasting and were being fed on flour contaminated with mycotoxins was highly significant. Clinical studies performed in Embu and Kakamega districts, Kenya, have also reported on the association between aflatoxin exposure and incidence of kwashiorkor (De Vries et al., 1990). Studies conducted in Sudan have indicated detection of aflatoxins in liver biopsies obtained from kwashiorkor children but none in biopsies from marasmus children (Hendrickse et al., 1983; Coulter et al., 1986). The correlation between occurrence liver cancer and kwashiorkor with aflatoxin exposure has also been reported in Ghana by Apeagyei et al., (1986). According to Adhikari et al. (1994), children with kwashiorkor who had tested positive for aflatoxin in blood and urine had statistically significant longer hospital stay and suffered more infections. 


\section{Immune suppression effect of aflatoxins exposure}

The immunosuppressive properties of $\mathrm{AFB}_{1}$, particularly on cell mediated immunity, have been demonstrated in various animal models (Bondy and Pestka, 2000). Studies on the immunotoxic effect of aflatoxin using animal models have shown that exposure to aflatoxin impaired macrophage and neutrophil effector functions in developing animals (Silvotti et al., 1997), suppressed natural killer (NK) cell-mediated cytolysis (Reddy and Sharma, 1989), decreased T or B lymphocyte activity (Reddy et al., 1987), modified synthesis of inflammatory cytokines (Moon et al., 1999), decreased immunity to vaccination (Gabal and Azam, 1998; Meissonier et al., 2008), and decreased resistance to infectious diseases (Joens et al., 1981).

There are limited studies on the immune effects of aflatoxin in humans exposed to low levels of aflatoxin in contaminated foods. In Gambia, Turner et al. (2003) studied modification of immune function through exposure to dietary aflatoxin in children and reported detection of aflatoxin albumin (AF-alb) adducts in $93 \%$ of the children (range $5-456 \mathrm{pgmg}^{-1}$ ). Immunoglobulin A (sIgA) was markedly lower in children with detectable AF-alb compared with those with non-detectable AFalb adduct levels. The sIgA provides an important component of the mucosal barrier in saliva, breast milk, tears, and mucus of the bronchial, genitourinary, and digestive tracts by binding to bacterial and viral surface antigens. In a separate study in Ghana (Jiang et al., 2005), the authors investigated the relationship between the cellular immune status and the levels of aflatoxin AF-alb adducts in plasma and reported AF-alb adducts levels ranged from 0.3325 to 2.2703 pmol $\mathrm{mg}^{-1}$ albumin. In the same study, the differential subset distributions and functional alterations of specific lymphocyte subsets between study participants with high and low levels of AF-alb adducts, showed decrease in activated $\mathrm{T}$ cells and $\mathrm{B}$ cells and significantly lower levels of perforin- and granzyme Aexpressing CD8+ cytotoxic $\mathrm{T}$ cells in those with high AF-alb adducts compared with those with low AF-alb adducts.

A study on aflatoxin-related immune dysfunction in health and in Human Immunodeficiency Virus (HIV) disease in Ghana (Jiang et al., 2008), observed that HIVinfected people are chronically exposed to aflatoxin in their diets. The following observations were also reported after crosssectional comparisons between HIV positive and aged-matched HIV negative Ghanaians with high ( $\geq 0.91 \mathrm{pmol} \mathrm{mg}^{-1}$ albumin) and low (< 0.91 pmol $\mathrm{mg}^{-1}$ albumin) AF-alb levels. First, among both HIV positive and negative participants, high AF-alb was associated with lower perforin expression on CD8+ T-cells. These results may indicate that $\mathrm{CD} 8+\mathrm{T}$-cells synthesizing perforin are impaired in individuals with high AF-alb. Secondly, HIV positive participants with high AF-alb had significantly lower percentages of CD4+ T regulatory cells (Tregs) and naive $\mathrm{CD} 4+\mathrm{T}$ cells compared to HIV positive participants with low AF-alb. The loss of Tregs in HIV positive participants with high AF-alb may facilitate HIV associated immune hyperactivation and lead to more severe disease. Third, HIV positive participants with high AF-alb had a significantly reduced percentage of B-cells compared to those with low AF-alb. These alterations in immunological parameters in participants with high AFB1 levels could result in impairments in cellular immunity that could decrease host resistance to infections. The underlying physiological mechanisms on the association between aflatoxin exposure, growth stunting and immune suppression, remain unclear and hence are important to investigate. According to Luster et al. (1987), the immunotoxicity effect is thought to result from various mechanisms such as decreased protein and, or DNA synthesis, changes or loss in enzymatic activity and changes in metabolism or cell cycles, which may result in apoptosis or necrosis 


\section{Determinants of chronic mycotoxin exposure in Kenya Socioeconomic factors}

High incidences of poverty levels coupled with limited education, especially amongst mothers, are some of the factors that contribute to dietary mycotoxin exposure and precipitation of malnutrition (Mustafa and Odimegwu, 2008). Due to the recurrent widespread drought, most households in rural Kenya face an acute food shortage and are vulnerable to food insecurity. It is, therefore, difficult to prioritize the issue of mycotoxin control in those communities in which food sufficiency has not been attained. Most families have no choice but consume the available food without regard to safety. The children and mothers bear the greatest burden of food insecurity in the rural communities. In a study by Okoth and Ohingo (2004), on the link between aflatoxin exposure and growth impairment amongst children, none of the mothers was aware of mycotoxins. However, $20 \%$ of the mothers appreciated that their flour would deteriorate with time and therefore had spoilage signs. The rest of the mothers used the flour as long as it lasted.

\section{Regulatory capacity}

There is lack of regulatory mechanism to routinely monitor food samples from the farms, distribution and market points. The ability of the regulators to enforce the mycotoxin standards requires that they must be capable of testing food for contamination. In Kenya, laboratories that are capable of analyzing foods for mycotoxin are limited, whereas the analytical procedures are very expensive (Moturi, 2008). Inspections are mostly done after outbreaks and are not used accordingly as pre-warning tools for the rural communities on impending mycotoxic risks. Furthermore, these samples are mostly obtained from local market centers, therefore excluding on-farm samples, which are consumed directly due to the subsistence nature of rural households. The contaminated maize is always destroyed but no further action is taken. Most of the food sampling by inspectors and researchers have focused on maize and ignored other important staple foods such as legumes, fish and meat commodities which could also have the potential to pose mycotoxic risks if contaminated by toxic fungi.

\section{Infant exposure due to dietary mycotoxins carry-over}

Several authors have reported the presence of mycotoxins, especially aflatoxins in the milk of farm animals, when they consume contaminated feeds (Bhat et al., 2010). This activity is common in the rural areas, especially when substandard farm produce are not discarded but instead fed to farm animals. A study by Jonsyn, (1999) in Sierra Leone, indicated that some local foodstuffs were contaminated with aflatoxins $B_{1}$ and $G_{2}$, Ochratoxin $A$ and reported that the major source of mycotoxin ingestion by infants was breast milk. The detection of aflatoxins and Ochratoxin A was observed in $88 \%$ and $35 \%$ of the milk samples contaminated respectively. In a study by Wild et al. (2006), it was reported that $11 \%$ of breast milk samples collected from women in rural villages in Zimbabwe, were found to be positive with aflatoxin levels up to $50 \mathrm{\mu gml}^{-1}$ of breast milk. Aflatoxin M1, which is a derivative of aflatoxin $\mathrm{B}_{1}$, has also been reported in human breast milk from Gambia (Zarba et al., 1992). These observations suggest that if the mother is exposed to dietary mycotoxicoses, there's likelihood of the mycotoxins being carried-over to the infants during breast feeding. Due to limited data in Kenya, there is need for further research into exposure of newborn children to aflatoxins through human breast milk and the interaction between aflatoxins exposure and infection during early life.

\section{Weaning status of the infants}

Weaning of infants onto family foods represents a period of increasing mycotoxin exposure. In a study by Gong et al. (2003) in Benin and Togo, aflatoxin exposure in young children was significantly related to weaning status in children 1-3 years of age, with mean 
aflatoxin-albumin (AF-alb) levels approximately 2-fold higher in fully weaned children compared with those receiving a mixture of breast milk and solid foods. Furthermore, the level of AF-alb was strongly associated with growth stunting. The most likely sources of mycotoxin exposure during the weaning periods are dietary staples frequently contaminated with mycotoxins such as maize or groundnuts (Setamou et al., 1997; Hell et al., 2000a, 2000b). According to Okoth and Ohingo (2004), 29\% of weaning food samples obtained from Kisumu district of Kenya, were positive for aflatoxins at ranges $2-82 \mu \mathrm{gkg}^{-1}$ when compared with the regulatory upper limit of $20 \mu \mathrm{gkg}^{-1}$ (KEBS, 1988).

\section{Co-occurrence of dietary mycotoxins}

In most tropical and humid developing countries such as Kenya, it is reported that various mycotoxins commonly occur at the same time as mixtures in the staple foods such as maize meal (Muriuki and Siboe, 1995; Kenji et al., 2000; Muture and Ogana, 2005; Mwihia et al., 2008; Mutegi et al., 2009; Muthama et al., 2009). Despite of the recognized human health effects of other toxins namely ochratoxins, deoxynivalenol, zearalenone, fumonisin and trichothecenes, most of the studies in Kenya are, however, still focused on aflatoxins poisoning. Mycotoxin poisoning may be compounded by the co-occurrence of aflatoxins with other mycotoxins (Bhat et al., 2010). The role of possible interactions between these cocontaminants and the underlying mechanisms of growth impairment is of public health interest. Some authors have suggested synergistic effect between various toxins while others have reported antagonistic interactions (Bankole, 2006).

\section{Pre-harvest and post-harvest practices}

Poor harvesting methods, improper transportation, marketing, processing and storage conditions can also contribute to fungal growth and increase the risk of mycotoxin production (Williams et al., 2004; Turner et al., 2005). Conditions such as unseasonal rains during harvest can lead to fungal proliferation and production of mycotoxins. These conditions were implicated in the 2004 aflatoxicosis outbreak in Kenya, which involved maize harvested during offseason, early rains (Lewis et al., 2005; Probst et al., 2007). Insect damage, cracking or breaking of maize kernels or groundnut shell during manual harvesting and presence of excessive chaff in the harvested grains also promote mould infection (Hell et al., 2000b). The practice of spreading crops on bare ground to sundry brings them in direct contact with soil fungal inoculums. There's need for awareness promotion on removal and destruction of debris of the previous harvest and cleaning of stores before loading new produce in order to reduce aflatoxin levels (Hell et al., 2000a).

According to Muthama et al. (2009), semi processed grains have lower isolation frequency of Fusarium spp and Aspergillus spp compared to the whole grain. It has also been found that commercial maize processing reduces mycotoxin levels, especially aflatoxins, which are concentrated in bran and germ. The traditional home processing of maize flour involves milling of the whole grain including the pericarp and the germ, which could imply inclusion of fungi and the associated mycotoxins. Most of the storage systems in use such as storing grains on the floors offer little protection against insect and mould deterioration (Naresh and Aldred, 2007).

\section{Possible intervention strategies to alleviate dietary aflatoxins exposure}

Given the potential adverse public health effects of the dietary mycotoxins, it is important to evaluate intervention strategies appropriate to rural populations in Kenya.

\section{Awareness strategies}

The strategies to mitigate the mycotoxin problem should include education of the rural population, especially the mothers on the prevalence and danger of mycotoxins in staple foods. In Kenya, there's need for fact 
sheets on the occurrence of mycotoxins to be developed for dissemination using simplified methods through community colleges (Kabak et al., 2006). Key part of the strategy should include awareness on preventive measures during pre- and post-harvest management of the farm produce. Mouldy grains and other foods suspected of being contaminated with mycotoxin should be discarded by burning. Dietary interventions should include the target areas with high mycotoxins exposure levels. This can be achieved through reduction of the frequent consumption of high risk foods and adoption of different methods that have less risk to prepare such staple foods. There should be targeted approaches for different stakeholders including community opinion leaders, farmers, consumers, policy makers, researchers, extension workers, nongovernment organizations (NGOs), donors, media, traders, processors, health workers and school children.

\section{Pre-harvest strategies}

Precautions should be taken during cultivation of crops to prevent fungal spores from being established during the growing period. The factors that influence potential for pre-harvest fungi to develop include physiological, morphological state of plant and climatic conditions (Setamou et al., 1997). Farmers should ensure that the seeds used for planting are certified and ensure they are free from pests and diseases while stored in the homesteads. Drought stress caused by lack of water facilitates attack by moulds by allowing the plant to crack resulting to open passage ways through which fungal spores can enter the crop stem or head (FAO, 2007). Where irrigation system is functional, farmers should always try to supplement local rainfall to avoid drought stress. If it is not possible to irrigate, they should plant and harvest as early as possible. Plant stress also occurs when nutrients are not available and leading to exposure of internal tissues which may be exposed to fungal attack. This can be overcome by appropriate application of organic and inorganic fertilizers.

Good plant husbandry is important in prevention of fungal invasion (Bhat et al., 2010). Even though minimal tillage is common amongst farmers due to savings on time and money, it is important to consider the possible negative effects. Without tillage, crop residues remain on the soil surface and eventually will harbour soil borne fungal spores, allowing them to infect the next crop (FAO, 1985). Other good plant husbandry measures include keeping the farm plots weed-free, control of insects by use of commercial insecticides applicants and other recommended methods of control such as botanical pesticides. Timing of the production cycle is also important and planting should be done at recommended time to avoid too early or too late maturity during periods of prolonged rainfall. Farmers should be encouraged to plant seed varieties that are pest and fungal resistant (FAO, 2007).

\section{Harvesting strategies}

The most important factors that influence mould growth once the plant is mature are water activity and physical damage. It is essential to dry the produce to safe moisture content as quickly as possible without causing any damage (FAO, 1985). Rapid drying requires that harvesting should be done as quickly and the crop transported to the homestead as soon as possible. The rate of drying will depend on the harvesting practices and crop involved. If the weather is dry and hot, the crops can be left standing in the field, but there is a risk of unexpected rainfall occurring during this period leading to mould growth. The common practice of cutting cereals at the base of stalk and pile stalks with cobs into conical bundles may inhibit ventilation and slow the drying process (FAO, 2007). Some farmers spread bundles of stalks especially legumes on the soil, which creates an opportunity for fungal spores in the soil to invade the grain. This can be avoided by 
placing a barrier between the crop and the soil or use of platform above the ground.

\section{Post-harvest strategies}

Drying begins before harvest and further drying is necessary until the crop is put in store (Turner et al., 2005). The crops can be spread on polythene preferably black or empty sacks laid on the ground or concrete floor. Unthreshed crop should be laid on platform or cobs can be tied and suspended from vertical frame to dry. Threshing, shelling and winnowing should be done carefully to avoid damaged grains. Farmers should avoid beating the crop with sticks which result in grain damage, eventually leading to mould development unless the grain is to be used quickly and not stored (FAO, 2007). Farm produce should be stored in suitable containers which are raised above ground level. If it has to be stored on the ground, farmers should use suitable water-proof barriers. However, if stored for more than two months, the grains should be treated with suitable grain protectants against insect damage. Further protection of the crop against damage by rodents is also necessary.

\section{Food processing strategies}

Various techniques are critical in mycotoxin removal or reduction. These include cleaning through sorting whether manual or mechanical, winnowing, sieving to remove screenings, washing through floatation or density segregation (Williams et al., 2004). Steeping is effective for fumonisins reduction; however there's need to change steep water often during a 48-hour steep period and use as much water as possible to steep maize. Dehulling and degerming are also effective for aflatoxins and fumonisins reduction (Muthama et al., 2009), while cooking and boiling is effective for aflatoxins and citrinin reduction in foods though the moisture content and cooking times are critical. The combined use of elevated temperature and pressure (extrusion cooking) has shown that fumonisins are effectively reduced. However, more information is needed to establish whether aflatoxins and citrinin are metabolized into other toxic compounds with heat treatment.

\section{Conclusion}

The occurrence of mycotoxins in the food chain is a serious problem that tropical developing countries such as Kenya are facing. Chronic exposure is particularly of great clinical importance due to the emerging evidence in their role in growth impairment and immune suppression. Given the high burden of infection-related mortality in Kenya, further investigation of the stunted growth and immune effects of aflatoxin exposure in children is merited. Comprehensive food safety program remains an important opportunity for addressing current mycotoxicosis problems in Kenya, particularly with regard to the achievement of the MDG 4 and 6 goals. These interventions must target all stakeholders including the market vendors, local farmers and rural households. Efforts should focus on the prevention of mycotoxin exposure by developing framework on strengthened surveillance and local education. The prioritization of other interventions will be largely guided by the availability of technology that can be applied in the short, medium and long term; and the impact of an intervention upon implementation.

\section{REFERENCES}

Adhikari M, Ramjee G, Berjak P. 1994. Aflatoxin, kwashiorkor, and morbidity. Nat. Toxins, 2: 1-3.

Apeagyei F, Lamplugh SM, Hendrickse RG, Affram K, Lucas S. 1986. Aflatoxins in the livers of children with kwashiorkor in Ghana. Trop. Geogr. Med., 38(3): 273276.

Azziz-Baumgartner E, Lindblade K, Gieseker K, Rogers HS, Kieszak S, Njapau H, Schleicher R, McCoy LF, Misore A, DeCock K, Rubin C, Slutsker L, Aflatoxin Investigative Group. 2005. Case-Control Study of an Acute 
Aflatoxicosis Outbreak, Kenya. Environ. Health Perspect., 113(12): 1779-1783.

Bankole S, Schollenberger M, Drochner W. 2006. Mycotoxins in food systems in Sub Saharan Africa: A review. Mycotox. Res., 22(3): 163-169.

Bhat R, Rai RV, Karim AA. 2010. Mycotoxins in Food and Feed: Present Status and Future Concerns. Compr. Rev. Food Sci. Food Safety, 9: 57 - 81.

Bondy GS, Pestka JJ. 2000. Immunomodulation by fungal toxins. $J$. Toxicol. Environ. Health Crit. Rev., 3(2): 109-143.

CBS (Central Bureau of Statistics), $\mathrm{MOH}$ (Ministry of Health). 2004. Kenya Demographic and Health Survey 2003. Calverton, Maryland: $\mathrm{CBS}, \mathrm{MOH}$, and ORC Macro.

CDC (Centers for Disease Control and Prevention) 2004. Outbreak of aflatoxin poisoning-eastern and central provinces, Kenya, January-July, 2004. Morb. Mortal. Wkly Rep., 53:790-792.

Coulter JBS, Hendrickse RG, Lamplugh SM, Macfarlane SBJ, Moody JB, Omer MIA, Suliman GI, Williams TE. 1986. Aflatoxins and kwashiorkor: clinical studies in Sudanese children. Trans. $R$. Soc. Trop. Med. Hyg., 80(6): 945-951.

DN (Daily Nation) newspaper, October $4^{\text {th }}$, 2001. Publication of Nation Media, Nairobi, Kenya.

De Vries HR, Maxwell SM, Hendrickse RG. 1990. Aflatoxin excretion in children with kwashiorkor or marasmic kwashiorkor-a clinical investigation. Mycopathologia, 110(1): 1-9.

Egal S, Hounsa A, Gong YY, Turner PC, Wild CP, Hall AJ, Hell K, Cardwell KF. 2005. Dietary exposure to aflatoxin from maize and groundnut in young children from Benin and Togo, West Africa. Int. J. Food Microbio., 104(2): 215-224.

FAO 1985. Prevention of Postharvest losses: a training manual. FAO training series no. 10, FAO, Rome.
FAO 2007. On farm mycotoxin control in food and feed grain (Golob P. Ed.). Good practices for Animal Feed and Livestock series no. 1, FAO, Rome.

Fung F, Clark RF. 2004. Health effects of mycotoxins: a toxicological overview. $J$. Toxicol. Clin. Toxicol., 42: 217 -234.

Gabal MA, Azzam AH. 1998. Interaction of aflatoxin in the feed and immunization against selected infectious diseases in poultry. II. Effect on one-day-old layer chicks simultaneously vaccinated against Newcastle disease, infectious bronchitis and infectious bursal disease. Avian Pathol., 27( 3): 290-295.

Gong YY, Cardwell K, Hounsa A, Egal S, Turner PC, Hall AJ, Wild CP. 2002. Dietary aflatoxin exposure and impaired growth in young children from Benin and Togo: Cross sectional study. Brit. Med. J., 325: 20-21.

Gong YY, Egal S, Hounsa A, Turner PC, Hall AJ, Cardwell KF. 2003. Determinants of aflatoxin exposure in young children from Benin and Togo, West Africa: the critical role of weaning. Int. J. Epidemiol., 32: 556-562.

Hell K, Cardwell KF, Setamou M, Poehling HM. 2000a. The influence of storage practices on aflatoxin contamination in maize in four agro-ecological zones of Benin, West Africa. J. Stored Prod. Res., 36: 365-382.

Hell K, Cardwell KF, Setamou M, Schulthess F. 2000b. Influence of insect infestation on aflatoxin contamination of stored maize in four agro-ecological regions in Benin. Afr. Entomol. 8: 169-177.

Hendrickse RG, Coulter JBS, Lamplugh SM, Macfarlane SBJ, Williams TE, Omer MIA, Suliman GI.1982. Aflatoxins and kwashiorkor: a study in Sudanese children. Brit. Med. J., 285: 843-846.

Hendrickse RG, Coulter JB, Lamplugh SM, MacFarlane SB, Williams TE, Omer MI, Suliman GI, El-Zorgani GA. 1983. Aflatoxins and kwashiorkor. Epidemiology and clinical studies in 
Sudanese children and findings in autopsy liver samples from Nigeria and South Africa. Bull. Soc. Pathol. Exot. Filiales. 76(5): 559-566.

Hendrickse RG. 1984. The influence of aflatoxins on child health in the tropics with particular reference to kwashiorkor. Trans. R. Soc. Trop. Med. Hyg., 78(4): 427-435.

Hendrickse RG. 1991. Clinical implications of food contaminated by aflatoxins. Ann. Acad. Med. Singapore. 20(1): 84-90.

Hendrickse RG. 1997. Of sick turkeys, kwashiorkor, malaria, perinatal mortality, heroin addicts and food poisoning: research on the influence of aflatoxins on child health in the tropics. Ann. Trop. Med. Parasitol. 91(7): 787-793.

Hinton DM, Myers MJ, Raybourne RA, Francke-Carroll S, Sotomayor RE, Shaddock J, Warbritton A, Chou MW. 2003. Immunotoxicity of Aflatoxin B1 in Rats: Effects on Lymphocytes and the Inflammatory Response in a Chronic Intermittent Dosing Study. Toxicol. Sci., 73: 362-377.

IARC (International Agency for Research on Cancer). 1993. Some naturally occurring substances: Food items and constituents, heterocyclic aromatic amines and mycotoxins. Aflatoxins. WHO IARC Monographs on the Evaluation of Carcinogenic Risks to Humans. 56: 245395. IARC, Lyon.

Ikamari LDE. 2004. An upsurge in early childhood mortality in Kenya: A search for explanations. Afri. J. of Health Sci. 11(1-2): 9-20.

Jiang YI, Jolly PE, Ellis WO, Wang JS, Phillips TD, Williams JH. 2005. Aflatoxin B1 albumin adducts levels and cellular immune status in Ghanaians. Int. Immunol., 17: 807-814.

Jiang Y, Jolly PE, Preko P, Wang J, Ellis WO, Phillips TD, Williams JH. 2008. Aflatoxin-Related Immune Dysfunction in Health and in Human Immunodeficiency Virus Disease. Clin.
Dev. Immunol., 2008, Article ID 790309 , 12 pages. doi:10.1155/2008/790309

Joens LA, Pier AC, Cutlip RC. 1981. Effects of aflatoxin consumption on the clinical course of swine dysentery. Am. J. Vet. Res., 42(7): 1170-1172.

Jonsyn FE. 1999. Intake of Aflatoxins and Ochratoxins by Infants in Sierra Leone: Possible effects on the general health of these children. J. Nutr. Environ. Med., 9(1): 15-22.

Kabubo-Mariara J, Karienyeh MM, Mwangi FK. 2006. Poverty, Child mortality and policy options for DHS surveys in Kenya: 1993-2003. $5^{\text {th }}$ PEP Research network General meeting, Addis Ababa, Ethiopia. pp 13.

Katere DR, Shephard GS, Faber M. 2008. Infant malnutrition and chronic aflatoxicosis in Southern Africa: is there a link? Int. J. Food Saf., Nutr. Publ. Health., 1(2): 127 - 136.

Kabak B, Alan DW, Dobson V. 2006. Strategies to Prevent Mycotoxin Contamination of Food and Animal Feed: A Review. Crit. Rev. in Food Sci. and Nutri., 46( 8): 593 - 619.

KEBS (Kenya Bureau of Standards) 1988. Dry-Milled Maize Products. Kenyan Standard No. 05158. Kenya Bureau of Standards, Nairobi (Kenya).

Kenji GM, Mvula AM, Koaze H, Baba N. 2000. Aflatoxin contamination of Kenyan Maize flour and Malted Kenyan and Malawian grains. Scientific Reports of the Faculty of Agriculture, Okayama University, 89: 5-7.

Lewis L, Onsongo M, Njapau H, Rogers HS, Luber G, Kieszak S, Nyamongo J, Backer L, Dahiye AM, Misore A, DeCock K, Rubin C, Kenya Aflatoxicosis Investigation Group. 2005. Aflatoxin contamination of commercial maize products during an outbreak of acute aflatoxicosis in Eastern and Central Kenya. Environ. Health Perspect. 113: 1763-1767. 
Lamplugh SM, Hendrickse RG. 1982. Aflatoxins in the livers of children with kwashiorkor. Ann. Trop. Paediatr., 2(3): 101-104.

Luster MI, Blank JA, Dean JH. 1987. Molecular and Cellular Basis of Chemically Induced Immunotoxicity. Annu. Rev. Pharmacol. Toxicol., 27: 2349.

Meissonnier GM, Pinton P, Laffitte J, Cossalter A, Gong YY, Wild CP, Bertin G, Galtier P , Oswald IP. 2008. Immunotoxicity of aflatoxin B1: Impairment of the cell-mediated response to vaccine antigen and modulation of cytokine expression. Toxicol Appl Pharmacol., 231(2): 142-149.

MPND (Ministry of Planning and National Development). 2005. MDGs status report for Kenya 2005. UNDP, GOK, Government of Finland.

Moon EY, Rhee DK, Pyo S. 1999. In vitro suppressive effect of aflatoxin B1 on murine peritoneal macrophage functions. Toxicol., 133(2-3): 171-179.

Moturi WN. 2008. Factors likely to enhance mycotoxin introduction into the human diet through maize in Kenya. Afri. J. Agric., Food and Nutri.. 8(3): 265- 277.

Muthama J, Muthomi W, Njenga LN, Gathumbi JK, Chemining'wa GN. 2009. The occurrence of aflatoxins in maize and distribution of mycotoxin-producing fungi in Eastern Kenya. Plant Pathol. J., 8(3): 113-119.

Mutegi CK, Ngugi HK, Hendrickse SL, Jones RB. 2009. Prevalence and factors associated with aflatoxin contamination of peanuts from Western Kenya. Int. J. Food Microbiol., 130(1): 27-34 .

Muriuki GK, Siboe GM. 1995.Maize flour contaminated with toxigenic fungi and mycotoxins in Kenya. Afr. J. Health Sci., 2(1): 236-241.

Muture BN, Ogana G. 2005. Aflatoxin levels in maize and maize products during the 2004 food poisoning outbreak in Eastern
Province of Kenya. East Afr. Med. J., 82: 275-279.

Mwihia JT, Straetmans M, Ibrahim A, Njau J, Muhenje O, Guracha A, Gikundi S, Mutonga D, Tetteh C, Likimani S, Breiman RF, Njenga K, Lewis L. 2008. Aflatoxin levels in locally grown maize from Makueni District, Kenya. East Afr. Med. J., 85(7): 311-317.

Naresh M, Aldred D. 2007. Post-harvest control strategies: Minimizing mycotoxins in the food chain. Int. J. Food Microbiol., 11(1-2):131-139.

Okoth SA, Ohingo M. 2004. Dietary aflatoxin exposure and impaired growth in young children from Kisumu District: Cross sectional study. Afr. J. Health Sci. 11(12): $43-54$.

Probst C, Njapau H, Cotty PJ. 2007. Outbreak of an acute aflatoxicosis in Kenya in 2004: identification of the causal agent. Appl. Environ. Microbiol. 73(8): 27622764.

Reddy RV, Taylor MJ, Sharma RP. 1987. Studies of immune function of CD-1 mice exposed to aflatoxin B1. Toxicol., $43(2)$ : 123-132.

Reddy RV, Sharma RP. 1989. Effects of aflatoxin B1 on murine lymphocytic functions. Toxicol., 54(1): 31-44.

Setamou M, Cardwell KF, Schulthes F, Hell K. 1997. Aspergillus flavus infection and aflatoxin contamination of preharvest maize in Benin. Plant Dis., 81: 13231327.

Shephard GS. 2008. Impact of mycotoxins on human health in developing countries. Food Addit. Contam., 25(2): 146 - 151.

Silvotti L, Petterino C, Bonomi A, Cabassi E. 1997. Immunotoxicological effects on piglets of feeding sows diets containing aflatoxins. Vet. Rec., 141(18): 469-472.

Terry MB, Susser E. 2001. Commentary: the impact of fetal and infant exposures along the life course. Int. J. Epidemiol. 30: 9596.

Turner PC, Moore SE, Hall AJ, Prentice AM, Wild CP. 2003. Modification of immune 
function through exposure to dietary aflatoxin in Gambian children. Environ. Health Perspect., 111: 217-220.

Turner PC, Moore SE, Hall AJ, Prentice AM, Wild CP. 2003. Modification of Immune Function through Exposure to Dietary Aflatoxin in Gambian Children. Environ. Health Perspect., 111: 217-220.

Turner PC, Sylla A, Gong YY, Diallo MS, Sutcliffe AE, Hall AJ, Wild CP. 2005. Reduction in exposure to carcinogenic aflatoxins by postharvest intervention measures in West Africa: A community-based intervention study. Lancet, 365: 1950-1956.

Wild CP, Pionneau FA, Montesano R, Mutiro CF, Chetsanga CJ. 2006. Aflatoxin detected in human breast milk by immunoassay. Int. J. Cancer. 40(3): $328-333$.

Wild CP. 2007. Aflatoxin exposure in developing countries: the critical interface of agriculture and health. Food Nutr. Bull., 28(2 Suppl): S372-380.

Williams JH, Phillips TD, Jolly PE, Stiles JK, Jolly CM, Aggarwal D. 2004. Human aflatoxicosis in developing countries: A review of toxicology, exposure, potential health consequences, and interventions. Am. J. Clinical Nutri., 80: 1106-1122.

Wagacha JM, Muthomi JW. 2008. Mycotoxin problem in Africa: Current status, implications to food safety and health and possible management strategies. Int. J. Food Microbiol., 124(1): 1-12

Zarba A, Wild CP, Hall AJ, Montesano R, Hudson GJ, Groopman JD. 1992. Aflatoxin M1 in human breast milk from The Gambia, West Africa, quantified by combined monoclonal antibody immunoaffinity chromatography and HPLC. Carcinogenesis, 13: 891-894. 